\title{
PENGARUH AUKSIN TERHADAP INDUKSI VIRUS PADA GUGUR DAUN TANAMAN CABAI
}

\author{
Amalan Tomia \\ Staf Pengajar FAPERTA UMMU-Ternate, $\boldsymbol{e}$-mail: -
}

\begin{abstract}
ABSTRAK
Zat pengatur tumbuh yang terpenting adalah auxin, gibberellin, dan sitokinin, tetapi bahan lain seperti ethylene dan inhibitor (penghambat) pertumbuhan, berperan penting dalam mengatur siklus hidup suatu tanaman. Tujuan penelitian ini adalah untuk mengetahui pengaruh auksin terhadap perkembangan gejala virus pada tanaman. Penelitian ini dilaksanakan di Laboratorium Bakteriologi Departemen Hama dan Penyakit Institut Pertanian Bogor. Berdasar Hasil uji Duncan (5\%) terlihat konsentrasi IAA 50 ppm dan 100 ppm dapat menekan terjadinya gugur daun yang disebabkan oleh virus (TMV) jadi semakin besar konsentrasi Auksin yang di induksi pada taman Cabai maka semakin meningkat pula ketahanan tanaman cabai terhadap inveksi Tomoto Mosaic Virus (TMV)
\end{abstract}

Kata Kunci: Auksin, induksi gugur daun

\section{PENDAHULUAN}

\subsection{Latar Belakang}

Pada dasarnya, tanaman tumbuh diatur oleh sejumlah kecil kelompok bahan yang terjadi secara alami yang bekerja sebagai hormon dan secara umum disebut sebagai pengatur tumbuh. Pengatur tumbuh yang terpenting adalah auxin, gibberellin, dan sitokinin, tetapi bahan lain seperti ethylene dan inhibitor (penghambat) pertumbuhan, berperan penting dalam mengatur siklus hidup suatu tanaman. Pengatur tumbuh bekerja dalam konsentrasi yang sangat kecil, dan terjadinya penyimpangan sedikit dari konsentrasi normal mungkin membawa perbedaan menyolok pada pola pertumbuhan tanaman (Agrios, 1997)

Goodman (1986) menyatakan bahwa pertumbuhan dan perkembangan tanaman secara biologi dikontrol oleh hormonal seperti komponen endogen yang aktif sebagai 3-indoleacetic acid (IAA, auksin), komponen yang berhubungan dengan indolat, giberelin, sitokinin, etilen, asam absisat dan sebagainya. Kandungan komponen dalam tanaman yang normal dapat berubah dengan adanya serangan patogenik. Kombinasi auksin dan etilen mempengaruhi kebiasaan pertumbuhan; auksin, asam absisat dan etilen mengontrol absisi daun dan lapisan semen. Patologi merubah level hormonal yang menyebabkan perubahan pertumbuhan tanaman dalam keadaan kombinasi seperti diatas, secara berurutan seperti gejala kerdil, tumorigenesis, epinasti dan keguguran daun prematur.

Sintesis auksin dipusatkan dalam daun muda dan pucuk tunas. Konsentrasi auksin dalam tanaman hijau bervariasi antara $10-0.1 \mu \mathrm{g} / \mathrm{ml}$ dengan gradien yang menurun dari jaringan muda ke jaringan tua. Pergerakan auksin dalam tanaman cepat, polar dan secara basipetal dalam floem. Pergerakan mungkin juga terjadi lebih lambat oleh difusi seluler dan juga basipetal. Auksin diproduksi oleh mikroorganisme dalam spektrum yang luas, terutama jika prekursor tersedia seperti triptofan

ABA disiapkan tanaman untuk dormansi. Secara spesifik ABA diaplikasikan pada pertumbuhan batang yang aktif untuk menginduksi gejala dormansi seperti ruas yang pendek, pembentukan bud scale, mengurangi aktivitas meristem dan beberapa absisi. Hormon tersebut juga menghambat pemecahan tunas dan pemanjangan secara genetik tall corn. Hal ini berlawanan dengan GA dan bertanggung jawab sebagai komponen aktif dalam respon tanaman pada fotoperiode pendek. Penambahan ABA mempertahankan dormansi biji yang secara normal berkecambah pada respon GA. ABA sebagai "metabolic brake" disebabkan oleh pengurangan fotoperiode.

Kloroplas merupakan salah satu dari organel sebagai tempat aksinya. Cara kerja ABA nampaknya menghambat sintesis RNA spesifik. 
Sebagai contoh ABA menghambat sintesis amilase kemungkinan berperan menghambat sintesis ensim spesifik RNA atau mencegah organisasi sintesis unit ensim. Kloroplas yang menjadi tua memberikan sejumlah besar prekursor dirubah menjadi ABA. Karena plastid dan kloroplas tempat utama sintesis GA, secara biologi kedengaran berlawanan sebagai hormon. ABA berpartisipasi dalam perusakan kloroplas. ABA memacu senesen, etilen diproduksi oleh organ senesen untuk memicu proses daerah lapisan absisi pada 3-5 sel yang cepat mensintesis pektin dan selulase.

Perlakuan dengan exogenus auksin dapat mempengaruhi perkembangan dari lesio. Aplikasi dari IAA atau 2-naphthylacetic acid dapat mengurangi ukuran lesio, ketika diaplikasikan pada yang muda, atau pada daun yang masih berkembang sebelum atau setelah infeksi, tidak ada pengaruh pada daun lebih tua atau daun yang rusak. Percobaa dengan 2,4-D agak menyimpang, ini dapat mereduksi ukuran lesio ketika diaplikasikan pada kosentrasi rendah tetapi menyebabkan pertambahan ukuran lesio pada kosentrasi tinggi. Penelitian sebelumnya oleh Simmon $d k k$ dengan menggunakan perlakuan IAA dapat mengurangi aktivitas dari peroksidase pada daun yang sebelumnya diinokulasi virus dan pada waktu yang sama akan terbentuk lesio lebih kecil, dua efek yang dipertimbangkan tidak berhubungan. Penelitian dari pengaruh auksin dapat distimulasi dengan ethepon (Ethrel, 2chloroethylphosphonic acid). Led van loon mengemukakan bahwa aksi dari auksin dapat ditengahi oleh produksi ethylen.

\section{I.2. Tujuan Penelitian}

Penelitian ini bertujuan untuk mengetahui pengaruh Zat pengatur tumbuh (IAA) terhadap perkembangan virus (TMV) penyebab gugur daun pada tanaman cabai.

\section{BAHAN DAN METODE}

\subsection{Bahan}

Bahan-bahan yang digunakan dalam penelitian ini adalah: satu liter garam potassium dari indol (IAA), pada konsentrasi berturut-turut: 1, 10, dan 100 ppm (disimpan pada suhu dingin); 80 bibit cabe yang ditumbuhkan pada tanah dalam pot pada kira-kira stadia 10 daun; sap dari daun tembakau yang terinfeksi TMV pada $10^{-3} \mathrm{mg} / \mathrm{ml}$ dalam $0,1 \mathrm{M}$ bufer fosfat $\mathrm{pH} 7,0$.

\subsection{Metode}

Penelitian ini menggunakan Rancangan Acak Lengkap (RAL) yang terdiri dari lima perlakuan yang diulang empat kali.

$$
\begin{aligned}
& \text { A } 0=\text { Kontrol } \\
& \text { A1 }=10 \mathrm{ppm} \\
& \text { A2 }=50 \mathrm{ppm} \\
& \text { A3 }=100 \mathrm{ppm}
\end{aligned}
$$

Setiap unit percobaan di ulang 5 sehingga terdiri dari 20 unit percobaan

Madel Matematika dari Rancangan Acak Lenkap adalah:

$$
Y_{i j}=\mu+j i+\varepsilon i j
$$

Dimana :

$\mathrm{Y}_{\mathrm{ij}}=$ Nilai tengah pengamatan

$\mu=$ Nilai rata-rata variabel

ji = Pengaruh konsentrasi ekstrak ke-i

eij = Galat percobaan atau pengaruh hasil percobaan.

Data yang telah diperoleh kemudian dianalisa dengan menggunakan ragam yang sesuai dengan rancangan yang digunakan, pengujian akan dilanjutkan sampai uji BNT (beda nyata terkecil) dengan taraf kepercayaan $95 \%$.

\subsection{Prosdur Kerja}

Daun begian bawah dari setengah tanaman diinokulasi dengan suspensi virus. Sebagai kontrol daun dari tanaman yang lain digosokgosok dengan bufer. Setiap tanaman yang diinokulasi disemprot secara menyeluruh dengan atomizer sampai basah menggunakan $0,1,10$, dan 100 ppm IAA. Semua perlakuan diulang 4 kali. Penyemprotan diulang pada interval 14 hari. Kemudian dihitung pada interval mingguan jumlah daun yang gugur untuk setiap perlakuan. Percobaan diakhiri setelah 4 minggu.

\section{HASIL DAN PEMBAHASAN \\ 3.1. Hasil}

Dari hasil pengamatan pengaruh Auksin terhadap gugur daun setelah induksi virus menunjukkan bahwa semakin tinggi konsentrasi Auksin (IAA) dapat mengurangi terjadinya gugur daun (Tabel 1).

Tabel 1. Pengaruh konsentrasi Auksin terhadap gugur daun akibat induksi virus.

\begin{tabular}{ccc}
\hline No & $\begin{array}{c}\text { Konsentrasi } \\
\text { IAA }(\mathrm{ppm})\end{array}$ & Rata-rata gugur daun \\
\hline 1 & 0 & $3.35 \pm 2.055 \mathrm{a}$ \\
2 & 10 & $2.25 \pm 1.291 \mathrm{a}$ \\
3 & 50 & $0.56 \pm 0.375 \mathrm{~b}$ \\
4 & 100 & $0.50 \pm 0.208 \mathrm{~b}$ \\
\hline *) rataan \pm simpangan baku &
\end{tabular}


*) angka yang diikuti oleh huruf yang sama pada setiap faktor berbeda nyata berdasarkan uji jarak berganda Duncan pada taraf nyata $5 \%$.
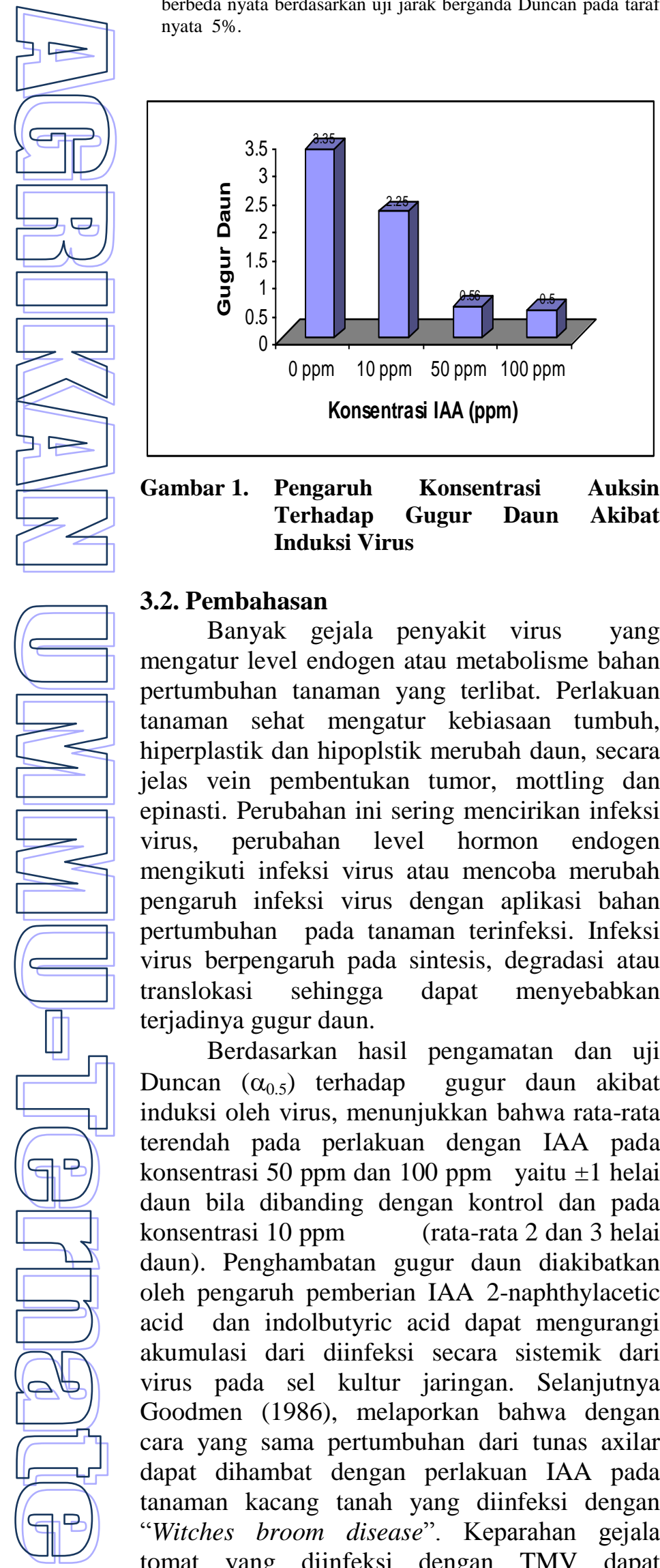

Gambar 1. Pengaruh Konsentrasi Auksin Terhadap Gugur Daun Akibat Induksi Virus

\subsection{Pembahasan}

Banyak gejala penyakit virus yang mengatur level endogen atau metabolisme bahan pertumbuhan tanaman yang terlibat. Perlakuan tanaman sehat mengatur kebiasaan tumbuh, hiperplastik dan hipoplstik merubah daun, secara jelas vein pembentukan tumor, mottling dan epinasti. Perubahan ini sering mencirikan infeksi virus, perubahan level hormon endogen mengikuti infeksi virus atau mencoba merubah pengaruh infeksi virus dengan aplikasi bahan pertumbuhan pada tanaman terinfeksi. Infeksi virus berpengaruh pada sintesis, degradasi atau translokasi sehingga dapat menyebabkan terjadinya gugur daun.

Berdasarkan hasil pengamatan dan uji Duncan $\left(\alpha_{0.5}\right)$ terhadap gugur daun akibat induksi oleh virus, menunjukkan bahwa rata-rata terendah pada perlakuan dengan IAA pada konsentrasi $50 \mathrm{ppm}$ dan $100 \mathrm{ppm}$ yaitu \pm 1 helai daun bila dibanding dengan kontrol dan pada konsentrasi $10 \mathrm{ppm} \quad$ (rata-rata 2 dan 3 helai daun). Penghambatan gugur daun diakibatkan oleh pengaruh pemberian IAA 2-naphthylacetic acid dan indolbutyric acid dapat mengurangi akumulasi dari diinfeksi secara sistemik dari virus pada sel kultur jaringan. Selanjutnya Goodmen (1986), melaporkan bahwa dengan cara yang sama pertumbuhan dari tunas axilar dapat dihambat dengan perlakuan IAA pada tanaman kacang tanah yang diinfeksi dengan "Witches broom disease". Keparahan gejala tomat yang diinfeksi dengan TMV dapat dikurangi dengan perlakuan dengan IAA dan pada tembakau yang diinfeksi dengan TMV dengan pemberian NAA atau IBA. Induksi virus yang dapat menggugurkan daun muda dapat juga ditunda dengan menyemprotkan IAA atau NAA pada Physalis floridana.

Perlakuan dengan exogenus auksin dapat mempengaruhi perkembangan dari lesio. Aplikasi dari IAA atau 2-naphthylacetic acid dapat mengurangi ukuran lesio, ketika diaplikasikan pada daun yang muda atau pada daun yang masih berkembang sebelum atau setelah infeksi. Percobaa dengan 2,4-D agak menyimpang, ini dapat mereduksi ukuran lesio ketika diaplikasikan pada kosentrasi rendah tetapi menyebabkan pertambahan ukuran lesio pada kosentrasi tinggi. Menurut Simmon dalam Meity (2003), bahwa perlakuan IAA dapat mengurangi aktivitas dari peroksidase pada daun yang sebelumnya diinokulasi virus dan pada waktu yang sama akan terbentuk lesio lebih kecil, dua efek yang dipertimbangkan tidak berhubungan.

Beberapa enzim IAA oksidase dan peroksidase dapat mengoksidasi auksin secara invitro, dan juga infeksi virus biasanya menunjukan penambahan aktivitas peroksidase, berhubungan dengan keparahan gejala ketika level IAA mungkin diharapkan untuk pengurangan timbulnya gejala pada daun. $\mathrm{CAB}$ International ( 2002) bahwa TMV dapat ditekan dengan cara menginduksi komponen antivirus atau berupa horman yang mampu meningkatkan ketahanan tanaman.

IAA pada tanaman dibutuhkan untuk perpanjangan dan differensiasi sel, dan penyerapan IAA untuk membran sel juga berpengaruh pada permeabilitas membrane sendiri mampu menghasilkan IAA. Pada beberapa penyakit, peningkatan IAA dapat secara menyeluruh atau sebagian karena degradasi peningkatan IAA dipengaruhi oleh penghambat IAA oksidase. Peningkatan IAA mempunyai kontribusi untuk perkembangan layu tanaman belum diketahui pasti, tetapi peningkatan plastisitas dinding sel merupakan hasil dari tingginya IAA menjadikan pektin, selulosa dan komponen protein dinding sel lebih accesible, dan mungkin memfasilitasi pendegradasiannya oleh masing-masing enzim yang dikeluarkan pathogen (Agrios, 1997) 


\section{KESIMPULAN DAN SARAN \\ 4.1. Kesimpulan}

Beradasarkan hasil dan pembahasan di atas maka dapat disimpulkan bahwa pada konsentrasi IAA $50 \mathrm{ppm}$ dan $100 \mathrm{ppm}$ dapat menekan terjadinya gugur daun yang disebabkan oleh virus (TMV).

\subsection{Saran}

Disarankan agar dilakukan penelitian lanjutan dengan skala besar untuk melihat aktivitas IAA dengan induksi virus maupun pada patogen lain.

\section{DAFTAR PUSTAKA}

Agrios GN., 1997. Plant Pathology. $4^{\text {th }}$ eds. Academic Press, Inc. San Diego.

[CABI] CAB International 2002. Crop Protection Compendium 2002 ed. [CD-RUM] London; CABI

Goodman, RN., Z. Kiraly dan KR. Wood., 1986. The Biochemestry and Physiology of Plant Disease. Univ. Missouri Press, Colombia.

Meity, S.S., 2003. Dasar-Dasar Ilmu Penyakit Tumbuhan. Penebar Swadaya Jakarta 